\title{
AGAMA DAN SEKULARISASI PADA MASYARAKAT MODEREN
}

\author{
Ellya Rosana \\ Universitas Islam Negeri Raden Intan Lampung \\ ellyarosana@radenintan.ac.id
}

\begin{abstract}
Religion in general can be interpreted as a system of beliefs and religious practices based on some sacred and supernatural values that direct human behavior, give meaning to life, and unite followers into a moral community. Although it cannot be denied that all religions of various kinds and forms today have experienced development. Religion is also believed not only to talk about rituals but also to talk. about values that must be concretized in social life, including in the realm of constitutionality there arises a demand for religious values to be applied in state life. Each adherent of religion believes that the teachings and values that are adopted must be upheld in the life of society and the state. The emergence of demands for the concretization of religious values in the life of the state that led to an unfinished debate about the relationship between state and religion, including secularism that separates religion and the state even though in fact in the secular religion of religion is not rejected at all, but religion must adjust the will of the community .
\end{abstract}

\section{Abstrak}

Agama secara umum dapat diartikan sebagai sistem kepercayaan dan praktikpraktik keagamaan yang berdasarkan beberapa nilai-nilai sakral dan supernatural yang mengarabkan perilaku manusia, memberi makna bidup, dan menyatukan pengikutnya kedalam suatu komunitas moral. Walaupun tidak. dapat dipungkiri bahwa semua agama dengan berbagai macam dan bentuknya dewasa ini telah mengalami perkembangan. Agama juga diyakini tidak banya berbicara soal ritual saja tetapi juga berbicara tentang nilai-nilai yang harus dikonkretkan dalam kehidupan sosial, termasuk dalam ranah ketatanegaraan 
muncul tuntutan agar nilai-nilai agama diterapkan dalam kehidupan bernegara. Masing-masing penganut agama meyakini bahwa ajaran dan nilai-nilai yang dianutnya harus ditegakean dalam kehidupan bermasyarakat dan bernegara. Munculnya tuntutan konkretisasi nilai-nilai agama dalam kebidupan bernegara yang memunculkan perdebatan yang tidak kunjung selesai mengenai relasi antara negara dan agama, termasuk. paham sekuler yang memisabkan antara agama dan negara walaupun sebenarnya dalam mayarakat sekuler agama tidak ditolak sama sekali, namun agama harus menyesuaikan kehendak masyarakat.

Keywords: Religion, Secularization, Modern Society

\section{A. Pendahuluan}

Agama merupakan aspek penting dalam kehidupan manusia. Agama pada umumnya memberikan jawaban terhadap pertanyaanpertanyaan yang sulit dijawab dan didekati dengan ilmu pengetahuan ilmiah. Misalnya mengapa manusia hidup dan mati, apa tujuan manusia hidup, dan sebagainya. Ketika agama dibenturkan dengan kemajuan zaman (modernisasi), maka hampir semua sarjana sosiologi menganggap bahwa agama akan tersisihkan perannya sebagai faktor legitimasi utama dalam masyarakat, digantikan oleh lembaga-lembaga kemasyarakatan yang dibentuk oleh masyarakat itu sendiri yang didasarkan pada ilmu pengertahuan.

Di zaman moderen sekarang ini, manusia di Barat sudah berhasil mengembangkan kemampuan nalarnya (kecerdesan intelektualnya) untuk mencapai kemajuan yang begitu pesat dari waktu kewaktu di berbagai bidang kehidupan termasuk dalam bidang sains dan teknologi yang kemajuannya tidak dapat dibendung lagi akan tetapi kemajuan tersebut jauh dari spirit agama sehingga yang lahir adalah sains dan teknologi sekuler. Pandangan masyarakat moderen yang bertumpu pada prestasi sains dan teknologi, telah meminggirkan dimensi transendental Ilahiyah. Akibatnya, kehidupan masyarakat moderen menjadi kehilangan salah satu aspeknya yang paling fundamental, yaitu aspek spiritual.

Sekularisasi merupakan fenomena masyarakat moderen yang muncul ketika semakin berkembangnya pemikiran yang berhubungan dengan modernitas. Sekularisasi muncul hampir bersamaan dengan 
proses makin memudarnya berbagai aspek sakral, baik pada tingkat masyarakat, individual, maupun agama. ${ }^{1}$

Sekularisasi yang melanda masyarakat moderen tidak dapat dibendung lagi karena tuntutan dari kemajuan ilmu pengetahuan dan teknologi.

\section{B. Urgensi Agama Pada Masyarakat Moderen}

Agama merupakan fenomena universal karena ditemukan dalam setiap masyarakat. Eksistensinya telah ada sejak zaman Prasejarah. Pada saat itu orang telah menyadari bahwa ada kekuatankekuatan lain di luar dirinya yang alih-alih bisa dikontrolnya, kekuatan-kekuatan tersebut bahkan mempengaruhi kehidupannya. Pada zaman tersebut, orang Yunani kuno misalnya sudah mulai memikirkan berbagai fenomena alam yang melingkupi dirinya dan mempertanyakan faktor-faktor penyebab terjadinya sesuatu. Hasil renungan yang dilakukan secara spekulatif ialah mitos-mitos yang diyakini kebenarannya oleh masyarakat. ${ }^{2}$

Agama pada awal sejarahnya merupakan suatu ajaran mengenai keselamatan dan kedamain di dunia dan akhirat, yang mana di dalamnya terdapat kepercayaan mengenai kesakralan, kemutlakkan suatu Zat yang dipercayai dengan penuh dan ajaran tentang nilai-nilai kemanusiaan sehingga tanggung jawab moral menjadi keutamaan dalam setiap tindakan yang dilakukan. Tetapi, pada kenyataan yang kita lihat dalam kehidupan kita ini masih terdapat individu atau kelompok yang dalam tindakan moralitasnya tidak berlandaskan nilainilai kemanusian.

Perbincangan tentang agama atau kepercayaan memang tidak akan pernah selesai, seiring dengan perkembangan masyarakat itu sendiri. Baik secara teologis maupun sosiologis, agama atau kepercayaan dapat dipandang sebagai instrument untuk memahami dunia. Dalam konteks itu, hampir-hampir tak ada kesulitan bagi agama apapun untuk menerima premis tersebut. Secara teologis, hal itu dikarenakan oleh watak omnipresent agama. Yaitu, agama, baik

1 Sindung Haryanto, Sosiologi Agama dari Klasik bingga Postmodern. (Yogyakarta : Ar-Ruzz Media, 2015), h. 268.

${ }^{2}$ Ibid, h. 21 
melalui simbol-simbol atau nilai-nilai yang dikandungnya "hadir di mana-mana", ikut mempengaruhi, bahkan membentuk struktur sosial, budaya, ekonomi dan politik serta kebijakan publik. ${ }^{3}$

Menurut Hendro Puspito, agama ialah sutu jenis sistem sosial yang dibuat oleh penganut-penganutnya yang berproses pada kekuatan sakral atau non-empiris yang dipercayai dan digunakan untuk mencapai keselamatan bagi individu atau sampai suatu kelompok masyarakat secara umum. Dalam kamus sosiologi pengertian agama ada 3 , yaitu : (1) kepercayaan pada hal-hal spiritual; (2) perangkat kepercayaan dan praktik-praktik spiritual yang dianggap sebagai tujuan tersendiri; dan (3) Ideologi mengenai hal-hal yang bersifat Supranatural. ${ }^{4}$

Agama dalam pengertian teologis sebagai seperangkat yang mengatur hubungan antar manusia dan Tuhannya, antara manusia dengan manusia lainnya, tak lagi dapat dipakai untuk gejala-gejala sosiologis hubungan interaksional timbal balik antara agama dan masyatakat. Alasannya, definisi agama seperti itu, ternyata lebih menekankan peran agama sebagai pengatur kehidupan dan kurang memberikan tekanan pada faktor manusia sebagai penganut penginterpretasi ajaran agama. ${ }^{5}$

Agama memberi makna pada kehidupan individu dan kelompok, juga memberi harapan tentang kelanggengan hidup sesudah mati. Agama dapat menjadi sarana manusia untuk mengangkat diri dari kehidupan dunia yang penuh penderitaan, mencapai kemandirian spiritual. Agama memperkuat norma-norma kelompok, sanksi moral untuk perbuatan perorangan, dan menjadi dasar persamaan tujuan serta nilai-nilai yang menjadi landasan keseimbangan masyarakat.

Dalam sosiologi secara garis besar terdapat perbedaan pandangan mengenai agama. Perbedaan pandangan tersebut dapat

${ }^{3}$ Kiki Muhamad Hakiki, Politik Identitas Agama Lokal (Studi Kasus Aliran Kebatinan), Analisis, Volume XI, Nomor 1, Juni 2011, h. 160.

h. 129

${ }^{4}$ Dadang Kahmad, Sosiologi Agama (Bandung :Remaja Rosdakarya, 2009),

${ }^{5}$ Nur Syam, Bukan Dunia Berbeda : Sosiologi Komunitas Islam, (Surabaya : Pustaka Eureka, 2005), h. 35-35 
dikategorikan ke dalam 3 perspektif, yakni perspektif fungsionalis, perspektif konflik, dan perspektif interaksionisme simbolik. ${ }^{6}$

Asumsi dasar teori fungsional bahwa masyarakat masyarakat sebagai sitem sosila terintegrasi oleh kesepakatan bersama (colective consciousness) yang membentuk fungsional anatarbagian sistem dalam keadaan saling ketergantungan (interdepencency). Dengan demikian kondisi masyarakat pada dasarnya selalu seimbang (Equilibrium). ${ }^{7}$

Perspektif fungsionalis yang dipelopori oleh Durkheim, berkeyakinan bahwa agama berfungsi sebagai perekat sosial (Social glue) yang dapat meningkatkan kesatuan dan solidaritas sosial. Fungsi tersebut dicapai melalui mekanisme introduksi doktrin-doktrin agama untuk meningkatkan emosional para pengikutnya dan menyelenggarakan ritual yang ditujukan untuk memantapkan hubungan sosial. Disamping itu, agama berfungsi untuk menetralisir kekacauan dari peubahan sosial.

Perspektif fungsionalis menganggap bahwa kedudukan agama menjadi sangat penting dalam masyarakat. Dalam berbagain etnografi masa lalu kita menyaksikan bagaimana agama berperan sebagai pemelihara keteraturan, pengendali moralitas, wahana pembenaran, dan pemberi sanksi bagi masyarakat. Dalam hal ini ritual menjadi manifestasi keyakinan agama ke dalam kelakuan dan tindakan, sehingga pengetahuan, keyakinan, dan nilai-nilai agama yang bersangkutan menjadi nyata dan operasional. Dengan kata lain, agama dapat dipandang sebagai kekuatan integratif yang menyatukan secara struktural-kultural unsur-unsur penyusunan masyarakat yang beraneka ragam. $^{8}$

Perspektif konflik menekankan bahwa agama mermpunyai peran penting bagi terjadinya perubahan sosial. Perspektif interaksionisme simbolik berpendapat bahwa agama berfungsi menyediakan kelompok referensi untuk membantu orang menemukan dirinya sendiri.

${ }^{6}$ Sindung Haryanto, Sosiologi Agama., h 26

7 Bagong Suryanto, Perkembangan dan Peran Sosiologi dalam J. Dwi Narwoko, Bagong Suyanto (Ed), Sosiologi, Teks Pengantar dan Terapan (Jakarta : Kencana Prenadamedia Group, 2006), h. 256

8 Ridwan Lubis, Sosiologi Agama Memahami Perkembangan Agama dalam Interaksi Sosial, (Jakarta : Prenamedia, 2015), h. vi 
Agama sebagai perbuatan (religion in action) mempunyai fungasi utama untuk mengurangi kegelisahan, memantapkan kepercayaan pada diri sendiri, dan yang penting memelihara manusia agar tetap siap menghadapi realitas. ${ }^{9}$

Selanjutnya disebutkan bahwa agama berperan dalam 3 kawasan kehidupan manusia yaitu : kawasan pertama adalah kawasan yang kebutuhan manusiawi dapat dipenuhi dengan kekuatan manusia sendiri. Manusia tidak perlu lari dari kekuatan adikodrati. Dalam hal ini manusia yang satu tidak sama dengan manusia yang lain. Bagi manusia yang masih berbudaya primitif, kawasan ini lebih sempit karena kemampuan dan pengetahuan mereka yang terbatas. Mereka lebih mudah lari pada hal-hal magis atau kekuatan gaib bila pengetahuannyan tidak dapat memecahkan persoalan hidupnya. Tetapi manusia moderen, dengan ilmu pengetahuan dan teknologinya memiliki kawasan yang lebih luas. Mereka dapat menyelesaikan berbagai persoalan dengan menggunakan akal budinya. Bagi mereka kekuatan adikodrati tidak diperlukan dalam usaha-usaha yang berdimensi netral.

Kawasan kedua meliputi wilayah yang manusia merasa aman secara moral. Tingkah laku dan tata pergaulan manusia diatur lewat norma-norma rasional yang dibenarkan agama, seperti norma sopan santun, norma hukum, serta aturan-aturan dalam masyarakat.

Kawasan ketiga, merupakan daerah yang manusia secara total mengalami ketidakmampuannya. Usaha manusia di daerah ini mengalami titik putus yang tidak dapat dilalui. Hal itu kemudian mendorong manusia mencari kekuatan lain di luar dirinya, yaitu kekuatan adikodrati. Maka terciptalah berbagai upacara ritual untuk berkomunikasi dengan kekuatan itu. Dengan itu, manusia meyakinkan dirinya sanggup mengatasi problem yang paling mendasar berupa ketidakpastian, ketidakmampuan, dan kelangkaan sehingga manusia merasa menemukan kepastian, keamanan, dan jaminan. ${ }^{10}$

Thomas F. O'Dea menyebutkan ada 6 fungsi agama. Pertama, agama mendasarkan diri manusia pada segala sesuatu di luar dirinya.

\footnotetext{
${ }^{9}$ Dadang Kahmad, Sosiologi Agama., h 121

${ }^{10} \mathrm{Ibid}$. Lihat juga Hendro Puspito, Sosiologi Agama, (Yogyakarta : Kanisius, 1983), h. 361
} 
Ia memberikan dukungan moral dari ketidakpastian hidup manusia, ia juga memberi berbagai alternatif penyelamatan dari kekecewaan dan kesedihan, serta kegelisahan manusia. Dengan demikian, agama menyediakan sarana emosional bagi manusia, menopang nilai-nilai dan tujuanyang telah terbentuk, memperkuat moral, dan membantu mengurangi kebencian.

Kedua, agama menawarkan suatu hubungan transedental melalui pemujaan dan peibadatan, dengan memberikan dasar emosional bagi rasa aman dan identitas yang lebih kuat ditengah ketidakspastiandalam hidupnya, serta dalam menghadapi perubahan sejarah dirinya.

Ketiga, agama mensucikan nilai-nilai dan norma-norma masyarakat yang telah dan akan terbentuk. Agama juga mempertahankan dominasi tujuan kelompok di atas keinginan individu. Menempatkan disiplin kelompok di atas kepentingan dan dorongan individu.

Keempat, agama memberikan standar nilai berupa normanorma yang telah terlembaga yang dapat dikaji kembali secara kritis. Kelima, agama memberikan fungsi identitas yang sangat penting. Agama memberikan kesempatan kepada individu untuk mengenal identitas dirinya. Keenam, agama berkaitan dengan emosional manusia. Perkembangan usia seseorang mempengaruhi karakteristik tingkat keberagamaan manusia. ${ }^{11}$

Selanjutnya Ridwan Lubis menyebutkan bahwa agama memerankan dua fungsi: pertama, menjelaskan suatu cakrawala pandang tentang dunia yang tidak terjangkau oleh manusia (beyond) yang dapat melahirkan deprivasi dan frustrasi yang bermakna. Selain itu, agama mengajarkan kesadaran terhadap pandangan dunia (world view) yang pada akhirnya melahirkan etos kerja sebagai pengejawantahan balasan ideal nyang akan diterima seseorang ketika di alam sesudah kebangkitan (eskhatologis). Kedua, agama sebagai sarana ritual yang memungkinkan hubungan manusia dengan hal yang di luar jangkauannya. Hubungan ini tumbuh dari akumulasi dua

11 Dadang Kahmad, Sosiologi Agama Potret Agama dalam Dinamika Konflik, Pluralisme dan Modernitas (Bandung : Pustaka Setia, 2011) h. 64-65. Lihat juga Thomas F. O’Dea, Sosiologi Agama suatu Pengenalan Awal (Jakarta : Rajawali, 1985) h. 26-29 
sikap yang pada dasarnya saling bertentangan, akan tetapi kemudian larut menjadi satu. Dua hal kontradiktif itu merupakan ketakutan dan kerinduan. ${ }^{12}$

Dari dua fungsi itu, maka secara lebih terinci dapat dilihat fungsi agama itu sebagai berikut : pertama, agama mendasarkan perhatiannya pada sesuatu yang berada di luar jangkauan manusia yang melibatkan takdir dan kesejahteraan. Kedua, agama menawarkan hubungan transedental melalui pemujaan dan ibadah sehingga memberikan dasar emosional bagi perasaan aman. Ketiga, agama menyucikan norma-norma dan nilai-nilai masyarakat yang telah terbentuk. Keempat, agama juga dapat memberikan standar nilai dalam penilaian kembali secara kritis noema-norma yang telah melembaga dan kebetulan masyarakat sedang membutuhkannya. Kelima, agama melakukan fungsi identitas yang penting. ${ }^{13}$

Secara sosiologis, kadar keberagamaan masyarakat juga memiliki pengaruh pada perilaku politik masyarakat. Dalam praktiknya agama diapresiasi oleh masyarakat secara berbeda. Setiap masyarakat mempunyai pola dan kadar keberagamaan yang berbeda dengan masyarakat lainnya. Atas dasar itu, tipe-tipe masyarakat dan agama dapat dibedakan. ${ }^{14}$

Tipe pertama, masyarakat yang terbelakang dan nilai sakral. Masyarakat yang mewakili tipe ini adalah masyarakat kecil, terisolasi dan terbelakang. Tingkat perkembangan teknik mereka rendah dan pembagian kerja atau pembidangan kelas-kelas sosial relatif masih kecil. Tipe kedua, masyarakat praindustri sedang berkembang. Masyarakat tipe ini tidak begitu terisolasi, berubahnya lebih cepat, daerahnya lebih luas dengan populasi yang lebih banyak serta memiliki teknologi yang lebih maju. Tipe ketiga, masyarakat industri dan sekuler. Masyarakat tipe ini sangat dinamis, teknologi semakin berpengaruh terhadap semua aspek kehidupan. Tipe keempat, percampuran antara tipe masyarakat di dunia moderen. Fenomena yang nampak semakin meningkatnya populasi masyarakat petani di

\footnotetext{
${ }^{12}$ Ridwan Lubis, Sosiologi Agama., h. 22-23

13 Bagong Suyanto, Perkembangan dan Peran, h. 256.

14 Dadang Kahmad, Sosiologi Agama., h. 125
} 
semua belahan dunia dan ekonomi bpertanian semakin lama semakin bergantung pada kondisi perdagangan dunia. ${ }^{15}$

Begitu pentingnya peran agama pada kehidupan masyarakat sehingga semoderen apa pun masyarakat seharusnya tidak dapat meninggalkan agama begitu saja karena agama merupakan alat kontrol manusia dalam berbuat dan bertingkah laku.

Agama selayaknya berfungsi menafsirkan kenyataan hidup dan mengarahkan, artinya memiliki fungsi interpretatif dan fungsi etis. Dalam perspektif ini, agama tidak hanyut dan tenggelam dalam politik, dan politik pun tidak memperalat agama. Fungsi interpretatif dan fungsi etis hanya mungkin dijalankan kalau agama dan politik tidak dicampuradukkan. Dalam situasi seperti itu interaksi antara agama dan politik akan menekankan dinamisme dan perubahan yang dituju, sehingga kehidupan bersama akan lebih merdeka dan adil. Tanpa dua fungsi ini agama akan mudah menjadi legitimasi atau diperalat oleh praktik politik atau praktik ekonomi yang tidak dapat dipertanggungjawabkan.

\section{Sekularisasi Pada Masyarakat Moderen}

Sekularisasi adalah paham yang mengutamakan kepentingan dunia. Sekularisasi merupakan fenomena yang ditandai oleh adanya pemisahan nilai-nilai dan norma keagamaan dengan kehidupan sehari-hari terutama dalam bidang politik dan ekonomi.

Sekularisasi merupakan pandangan hidup yang berprinsip bahwa agama tidak boleh masuk dalam pemerintahan. Begitu juga yang menyangkut pertimbangan-pertimbangan agama tidak diperkenankan masuk ke dalam wilayah pemerintahan. Sekularisasi bahkan memisahkan agama dari kehidupan individu maupun sosial dalam arti bahwa agama tidak boleh berperan dalam bidang pendidikan, kebudayaan, maupun hukum.

Sekularisasi berasal dari bahasa secular yang berasal dari bahasa latin saeculum yang artinya ialah abad atau dunia. Adapun pengertian 
menurut istilah politik ialah pendapat yang mengatakan bahwa soal kenegaraan haruslah tidak terdapat unsur-unsur keagamaan. ${ }^{16}$

Dalam konteks pemikiran ini dunia dan nilai dunia dipisahkan sama sekali dari agama, dan demikian juga dinilai baik. Jadi bukan hal yang jahat atau tercela. Dari kata dasar "saeculum" dibentuk kata "saecularis"atau "secular" yang diberi arti "serba duniawi" dalam arti yang baik. Lebih lanjut dari kata yang sama muncul pengertian "sekularisme" dan "sekularisasi". Yang pertama termasuk golongan ideologi, dan yang kedua berupa suatu gerakan. ${ }^{17}$

Dalam perkembangan terakhir istilah tersebut didenotasikan sebagai perluasan ide "semangat dari suatu abad". Dalam khasanah teori sosiologi agama, istilah sekuler diidentikkan dengan "profan" (keduniaan) yang merupakan antonim dari sacred (suci, ilahi). ${ }^{18}$

Sekularisasi adalah paham yang memisahkan agama dari hidup dan kehidupan manusia. Manusia sekuler memandang agama sebagai masalah pribadi dan menolak campur tangan agama dalam ranah publik. Sudah tentu lahirnya sekularisasi di barat memiliku latar belakang sejarah yang panjang. Akar historis kemunculan kemunculan sekularisasi di barat tak dapat dilepaskan dari paham pemisahan agama (crunch) dari negara (state). Sedangkan agama saat ini merupakan realitasa yang berada di sekeliling manusia. Masingmasing manusia memiliki kepercayaan tersendiri akan agama yang dianggapnya sebagai sebuah kebenaran. Agama yang telah menjadi kebutuhan dasar manusia ini tidak dapat dipisahkan dari kehidupan sosial manusia tersebut.

Konsep sekularisasi mengacu pada proses dengan mana pengaruh agama atas banyak bidang kehidupan sosial secara mantap berkurang. Sekularisasi merupakan kecenderungan pokok dalam masyarakat barat dalam beberapa tahun lalu atau sekurang-kurangnya sejak munculnya industrialisasi. Kemajuan ilmu pengetahuan, industrialisasi, urbanisasi,dan rasionalisasi dan modernisasi masyarakat telah menyebabkan agama semakin surut dari arena

16 Yunan Nasution, Islam dalam Problem-problem Kemasyarakatan. (Jakarta : Bulan Bintang, 1998) h. 70-71 2002), h. 75

17 Ishomuddin, Pengantar Sosiologi Agama, Jakarta : Ghalia Indonesia,

18 Sindung Haryanto, Sosiologi Agama., h. 268 
kehidupan sosial yang dikuasainya secara tradisional. Sekularisasi adalah paham dan sikap bahwa hidup ini semata-mata untuk kepentingan dunia terlepas dari nilai dan norma agama. Ciri-ciri sekularisasi adalah semata-mata berorientasi kepada masalah keduniaan dan tidak terikat oleh nilai keagamaan ( hedonisme).

Dalam teori sosiologi agama, proses sekularisasi menurut Wilson dikaitkan dengan proses modernisasi dan industrialisasi. Masyarakat postindustrial dicirikan hilangnya sistem sosial yang penuh moral sebagai tatanan sosial yang kemudian bergeser menjadi semakin impersonal. ${ }^{19}$ Kemajuan teknologi dan ekonomi menimbulkan akibat pada struktur masyarakat serta hubungan antar orang dalam masyarakat. Bagaimana kiesempatan baru itu dilakukan dan dinilai sangat bergantung pada sistem hidup yang berkembang dalam masyarakat yang bersangkutan serta kaidah-kaidah sosial yang berkaitan dengan itu. Dapat dikatakan bahwa masyarakat manusia sedang mengalami evolusi, dari masyarakat tradisional menuju masyarakat moderen. Meskipun demukian, proses modernisasi dan bentuk modernisasi yang dicapai oleh masyarakat akan berbeda-beda.

Sebagaimana dijelaskan oleh Piotr Sztompka bahwa modernitas (modernisasi) sangat mempengaruhi kehidupan manusia baik dalam bidang ekonomi, politik, stratifikasi, dan kehidupan sehari-hari. Dalam bidang kultur dapat dilihat 4 fenomena penting:

1. Sekularisasi; merosotnya arti penting keyakinan agama, kekuatan gaib, nilai, dan norma, dan digantikan oleh gagasan dan aturan yang disahkan oleh argumen dan perimbangan "duniawi"

2. Peran sentral ilmu yang membuka jalan untuk mendapatkan pengetahuan yang benar dan selanjutnya dimanfaatkan dalam bentuk teknologi atau kegiatan produktif

3. Demokratisasi pendidikan yang menjangkau lapisan penduduk yang makin luas dann tingkat pendidikan yang makin tinggi

${ }^{19}$ Ibid, h. 271 
4. Munculnya kultur massa; produk estetika, kesusastraan, dan artistik berubah menjadi komoditi yang tersebar luas di pasar dan menarik selera semua lapisan sosial. ${ }^{20}$

Dalam kehidupan sehari-hari pun mengalami perubahan, dengan adanya fenomena berikut :

1. Perluasan bidang pekerjaan dan pemisahannya dari kehidupan keluarga

2. Pertumbuhan kemandirian (privatization) keluaga dan pemisahannya dari kontrol sosial komunitas atau masyarakat lebih luas

3. Pemisahan antara waktu untuk bekerja dan waktu untuk santai, dan waktu untuk bersantai makin banyak

4. Peningkatan konsumerisme. Kehidupan sehari-hari tertuju pada pendapatan dan konsumsi barang yang dianggap sebagai simbol peran yang penting. ${ }^{21}$

Modernisasi yang terjadi mencakup pengertian perubahan dalam bidang ekonomi, politik, sosial, dan budaya. Sejalan dengan kemajuan teknologi komunikasi dan transformasi, mobilitas sosial semakin tinggi sehingga terjadinya suatu sistem nilai dan kepercayaan masyarakat berubah sehingga terjadi proses sekularisasi dan memudarnya fungsi agama.

Proses modernisasi telah mentransformasikan seluruh struktur sosial, tidak terkecuali institusi agama. Teori sekularisasi yang berkembang dalam sosiologi agama menyatakan bahwa proses modernisasi mempunyai efek negatif terhadap kebangkitan komunitas agama beserta konsekuensinya, seperti aktivitas keagamaannya. Terdapat asumsi yang mendasari teori ini, yakni bahwa modernisasi mensyaratkan rasionalitas, sedangkan dalam istitusi agama terdapat nila-nilai atau unsur-unsur yang irasional bahkan suprarasional. Oleh karena itu, institusi agama secara perlahan mulai ditinggalkan seiring dengan proses modernisasi. Jika modernisasi merupakan keniscayaan di hampir semua masyarakat, 2004), h. 88

20 Piotr Sztompka, Sosiologi Perubahan Sosial Jakarta : Prenada Media, ${ }^{21}$ Ibid 
dapat pula diasumsikan berdasarkan teori sekularisasi bahwa sekularisasi juga merupakan keniscayaan di semua penjuru dunia. ${ }^{22}$

Sekularisasi yang merupakan bagian dari modernisasi juga telah menunjukkan sisi buruknya. Dalam masyarakat moderen, dimns institusi-institusi sekuler telah memasuki ranah publik (public atmosphere), nampak jelas bahwa berbagai gagasan religiun dan institisi-institusi keagamaan semakin diprivatisasikan dan simarginalkan sebagai institusi non formal dan cenderung tergeser oleh rasionalita.

Sekularisasi tidak hanya melingkupi aspek-aspek politik dan sosial kehidupan, bahkan telah memasuki aspek kultural, karena hal ini menunjukkan hilangnya determinasi religius dari simbol-simbol integral kultural. Sekularisasi menyiratkan suatu proses historis, dimana masyarakat dan kultur bebas dari perwalian kontrol religius dan pandangan-pandangan dunia metafisis yang tertutup. Sekularisasi menjadi suatu perkembangan pembebasan, dan hasil akhirnya adalah relativisme historis. ${ }^{23}$

Sekularisasi mempunyai ciri-ciri :

1. Berorientasi semata-mata pada masalah keduniaan

2. Tidak terikat dengan (atau mengenyampingkan) nilai-nilai keagamaa. $^{24}$

Sekularisasi merupakan gerakan (sosial) yang diarahkan pada terwujudnya otonomi dunia dan nilai duniawi dengan mengikutsertakan agama dan nilai-nilai keagamaan. Sedangkan gerakan sekuler yang tidak mengikutsertakan Tuhan dan nilai-nilai keagamaan disebut dengan istilah sekularisme dalam arti peyoratif (negarif). Maka anggapan umum sekarang ini ialah bahwa sekularisasi mempunyai arti positif dan dapat diterima. Sedangkan sekularisme diberi arti jahat dan harus ditolak. Dalam semua gerakan penduniaan (sekularisasi), faktor kekuatan alam, dan kemampuan manusia memegang peranan utama. Faktor-faktor agama yang bersifat tahayul

22 Sindung Haryanto, Sosiologi Agama., h. 273

23 Fahim Tharaba, Sosiologi Agama Konsep, Metode Riset, dan Konflik Sosial, (Malang : Madani, 2006), h. 168

24 Abdulsyani, Sosiologi, Skematika, Teori dan Terapan, (Jakarta : Bumi Aksara, 1994), h. 178 
dan mitologis disingkirkan jauh-jauh. Tetapi nilai-nilai religius yang telah dibersihkan dari unsur-unsur tahayul dan mitologis dipersilakan memberikan pengaruh baiknya. ${ }^{25}$

Islam menolak sekularisasi sebab ajaran Islam mencakup seluruh bidang kehidupan manusia termasuk dalam bidang kenegaraan. Dalam Islam tidak ada pemisahan antara urusan agama dan urusan politik. Politik sebagai suatu kegiatan harus dilakukan dalam kerangka sistem nilai Islam. Namun demikian Al-Qur'an dan Sunnah Rosulullah tidak membatasi pengaturan kenegaraan tersebut secara kaku. Hal tersebut diserahkan kepada umatnya melalui Ijtihad.

\section{Penutup}

Sekularisasi menganggap bahwa hidup semata-mata hanya untuk memenuhi kebutuhan duniawi dengan meninggalkan unsurunsur nilai religius/ keagamaan. Sekularisasi pada masyarkat sangat berpengaruh yang dapat mengubah perilaku masyarakat untuk mengejar kesenangan duniawi yang berorientasi pada materi dan teknologi. Agama dan kepercayaan hanya sebagai pemenuhan kebutuhan seremonial belaka, bukan sebagai pandangan hidup.

Manusia yang menganut paham sekularisme berusaha menikmati kehidupan dan kemajuan selama ini seolah-olah tanpa campur tangan Tuhan. Dan menganggap Tuhan tidak perlu lagi. Karena itu, tempat Tuhan digantikan oleh ilmu pengetahuan dan teknologi yang dianggap sebagai dewa penyelamat.

Pada masyarakat sekuler, agama hanya terlibat sedikit dalam kehidupan. Mungkin terlalu pagi untik mengatakan bahwa masyarakat moderen dapat berfungsi tanpa agama, atau bahwa masyarakat itu berfungsi sendiri. Masyarakat sekuler masa kini, dimama pemikiran, praktik, dan institusi keagamaan hanya merupakan bagiankecil saja, hanya mewariskan sedikit nilai-nilai, watak dan orientasi masa lampau.

Sekularisasi merupakan kekuatan yang tak dapat dicegah, yang akan memuncak pada saat surutnya agama yang terorganisasi, selain

25 Pardoyo, Sekularisasi dalam Polemik, Jakarta : Pustaka Utama Grafiti, 1993), h. 75-76 
itu juga membawa dampak negatif bagi masyarakat. Oleh karena itu agama dan kepercayaan harus tetap tumbuh dan berkembang serta dipertahankan dalam kehidupan masyarakat agar dapat menjadi benteng/penghalang terhadap munculnya tindakan dan perilaku menyimpang yang ditimbulkan. Munculnya pranata agama difungsikan untuk mengatur hubungan antara manusia dengan Tuhannya. Dengan terus menjalankan perintah-Nya dan menjauhi larangan-Nya maka akan terbentuk masyarakat yang tidak akan terpengaruh dengan sekularisasi. 


\section{Daftar Pustaka}

Abdulsyani, Sosiologi, Skematika, Teori dan Terapan Jakarta : Bumi Aksara, 1994

F. O'Dea, Thomas, Sosiologi Agama suatu Pengenalan Awal Jakarta : Rajawali, 1985

Hakiki, Kiki Muhamad, Politik Identitas Agama Lokal (Studi Kasus Aliran Kebatinan), Analisis, Volume XI, Nomor 1, Juni 2011.

Haryanto, Sindung, Sosiologi Agama dari Klasik hingga Postmodern. Yogyakarta : Ar-Ruzz Media, 2015

Ishomuddin, Pengantar Sosiologi Agama, Jakarta : Ghalia Indonesia, 2002

Kahmad, Dadang, Sosiologi Agama Bandung :Remaja Rosdakarya, 2009

- Sosiologi Agama Potret Agama dalam Dinamika Konflik, Pluralisme dan Modernitas, Bandung : Pustaka Setia, 2011

Lubis, Ridwan, Sosiologi Agama Memahami Perkembangan Agama dalam Interaksi Sosial, Jakarta : Prenamedia, 2015

Nasution, Yunan, Islam dalam Problem-problem Kemasyarakatan. Jakarta : Bulan Bintang, 1998

Pardoyo, Sekularisasi dalam Polemik, Jakarta : Pustaka Utama Grafiti, 1993

Puspito, Hendro, Sosiologi Agama, Yogyakarta : Kanisius, 1983

Suryanto, Bagong, Perkembangan dan Peran Sosiologi dalam J. Dwi Narwoko, Bagong Suyanto (Ed), Sosiologi, Teks Pengantar dan Terapan, Jakarta : KencanaPrenadamedian Group, 2006

Syam, Nur, Bukan Dunia Berbeda: Sosiologi Komunitas Islam, Surabaya : Pustaka Eureka, 2005

Sztompka, Piotr, Sosiologi Perubahan Sosial, Jakarta: Prenada Media, 2004 
Agama dan Sekularisasi

Tharaba, Fahim, Sosiologi Agama Konsep, Metode Riset, dan Konflik Sosial, Malang : Madani, 2006 